\title{
The Use of Technologies in Second Language Learning: The Case of a Mexican University
}

\author{
MA. Maria del Carmen Hernandez Cueto \\ MA in ELT. Marcela Garcia Ramos \\ MA in ELT. Maria Georgina Ochoa Garcia \\ MA. Yun Sang Cheol. \\ Autonomous University Of The State, Mexico
}

doi: 10.19044/esj.2017.v13n25p264 URL:http://dx.doi.org/10.19044/esj.2017.v13n25p264

\begin{abstract}
Introduction: This research is about the use of technology in learning English as a Foreign Language at higher education in a public University in Mexico. This study is focused on how students use the technology for academic and non-academic issues to learn English.

The object of the study a sample of twenty five percent of English language students (375 students) were considered. Students' average age was 18-25.

Methodology: For this research two instruments were used to gather data the first one a questionnaire designed for this purpose, the second one an interview to know what kind of gadgets students use to learn English in higher education and how this technology could be introduced in second language learning classrooms.

The results: allowed concluding that most technological gadgets used by students were Cells and Laptops to surf the net and chat through social networks for non-academic issues and laptops and desktop computers to work on school duties with specific software.
\end{abstract}

Keywords: English, learning, gadgets, academic, higher education

\section{Introduction}

The use of the technology has been spreading worldwide and it has changed our lives and the form to communicate with others. This change has impacted on the field of the education, the needs and opportunities to learn in different forms to get the same goal to acquire knowledge for life. Nowadays, young students are known as digital natives and use technologies and digital communication as second nature (Goodwin-Jones, 2005). It is possible to see digital natives in the field of education especially at university 
levels where students feel more interested and engaged with all those activities which involve technologies.

According to Murray (2005) the use of technologies with new generation students provide a natural context for learner autonomy, context for learner identity, new ways to use language and motivation for students creating in these forms new opportunities of collaboration and interaction between teachers and students. Besides, many students use a lot of digital devices such: the internet, blogs, chats, what's, computers, cell phones, tablets and some other technological devices are part of their everyday life. At the same time, they make a comparison with the time they spend reading, studying and writing about academic subjects, which is a minimal part of their everyday activities. Afterwards, this exposition of situations we could think that students enjoy reading, writing, listening although probably they just have a different form to do it.

For some time, in The State University of Nayarit (UAN) in Mexico, teachers of English as a foreign language have been trying to integrate the use of technologies in their classrooms, but most of these technologies are quite basic and sometimes already out of date. For these reasons, students often do not feel motivated by or willing to engage with activities that include these types of technologies. In second language teaching it is very common to use audio and video devices to support regular classes but frequently teachers are a step behind their students. For example, when teachers need to use audio for the class some of them use Tape recorders and the most updated teachers a CD player, however students use IPhones, cell phones, Laptops, IPAD, tablets, and to watch videos they use YouTube, blogs on the internet, video on snapchat, Instagram, and vine. To communicate they use whats, messenger and Instagram with private messages.

\section{Statement of the problem}

Despite the fact that students at the State University of Nayarit are usually highly familiar with and motivated by the use of new technologies for different purposes, although, it seems that they do not use such technologies to learn English or with academic purposes to engage themselves in English learning process. This research project aims to find out why this is and what can be done to improve this situation?

\section{The gap}

The UAN is a public university and most of the students do not have a high income, even though it is common to see many students that have their own laptop, cell phone and other attractive technologies for young people. These students spend large amounts of time using the internet, social 
networks, chat rooms, messenger, and so on. This leads to the question about how many students use these elements for education? How many students read books online? How many of them search for academic information?

\section{The purpose of this study}

This research project aims to study the extent to which students take advantage of the use of technology for academic purposes and engage themselves in learning English as a second language, what can be done to improve this situation? To achieve this purpose, two related research questions are devised to orient the study.

\section{Research questions}

RQ1. What are the affordances of new technologies used by students at the State University of Nayarit and what are their purposes for the use of these technologies?

RQ2. How could new technologies be best integrated in second language learning at the State University of Nayarit?

\section{Literature Review}

New technologies are directly linked to information and communication technologies (ICT's). They are defined in terms of capability to acquire, to process and to transmit information and they are in constantly change with time (Steinmueller, 2000).

Due to the need to improve students' skills to become skilled workers, the field of education is trying to catch up with these entirely new phenomena and changing conditions to provide students with a set of tools to respond to the world's changing needs. Many countries and their authorities have decided that education should change. For this reason people should ask about what is happening with education? What are teachers doing to provide students with new competitive skills? Have teachers change from traditional teaching models to new models? Are students really getting new skills? Although Mexico is not a high economical developed country this dynamic is causing effects in its educational context, for this reason private and public universities such as the State University of Nayarit need to work on strategies in order to provide students the required characteristics to face the competitive demand of job offers.

\section{Methodology}

For this research project a mixed approach was employed. The qualitative approach deals with students of English as a foreign language to know about their points of view about the use of technologies for second language learning at the State University of Nayarit, this information was 
gathered by interviews with students. The quantitative approach focused on the types of technologies and the average time they spend using them. This information was gathered by a questionnaire applied to students.

\section{The sample}

The population origin is from a Mexican Public University, and it was of one thousand five hundred of English Language Students, for this study a sample of twenty five percent (three hundred seventy five) of the students was taken. Students came from different schools and their majors' too. Students' average age was among 18 and 25 years old.

\section{Results and analysis}

The most used technological gadgets used by students are PC's, laptops, internet, cell phones, and social networks among others. (See figure 1)

As a remarkable aspect, $89 \%$ of the students considered the cell phone (smart phones) as the most important technological resource they use, setting this gadget as the number one for students. Although the main use of cell phones should be to make phone calls, curiously, they are not the number one use for students.

Students mentioned that messaging is their number one priority for a cell phone use, becoming phone calls a secondary use among others, such as listening to music, surfing the net and use the date book application included in cell phones. (See figure 2)

Figure 1 Technological gadgets used by students for non-academic issues

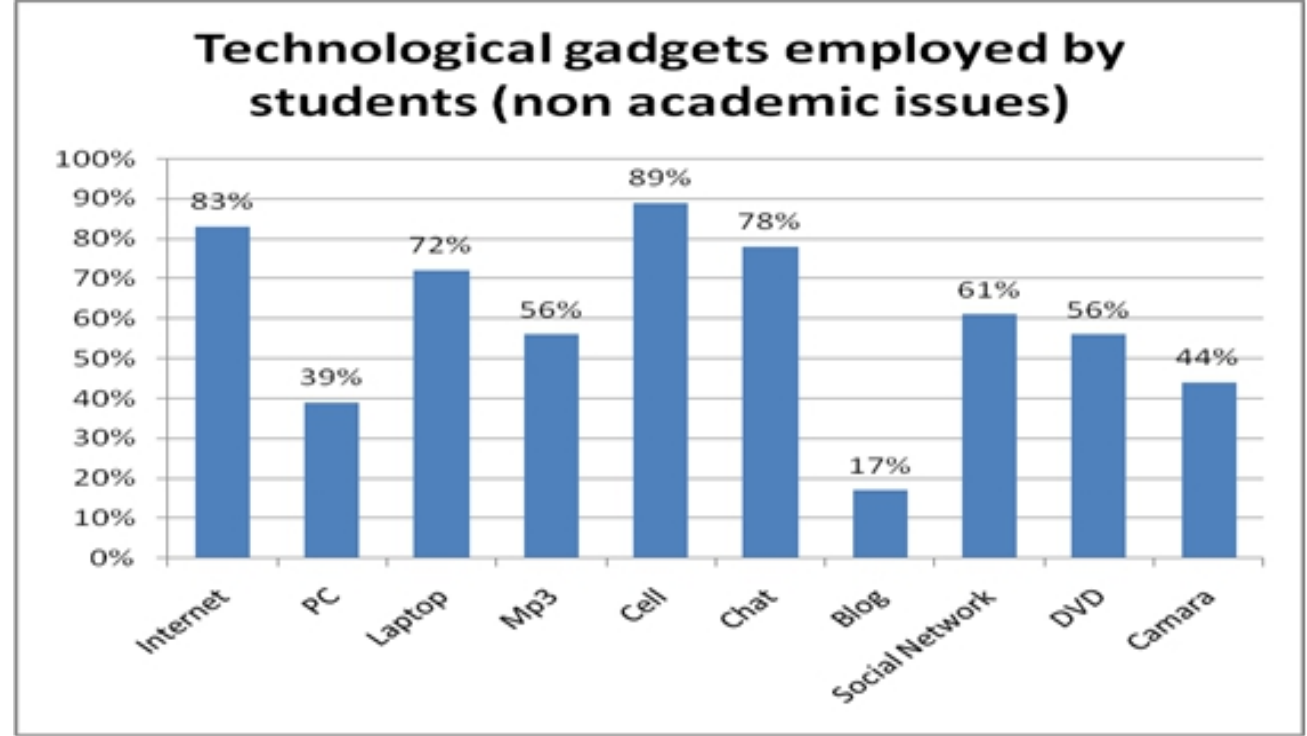


Figure 2 Uses of cell phone

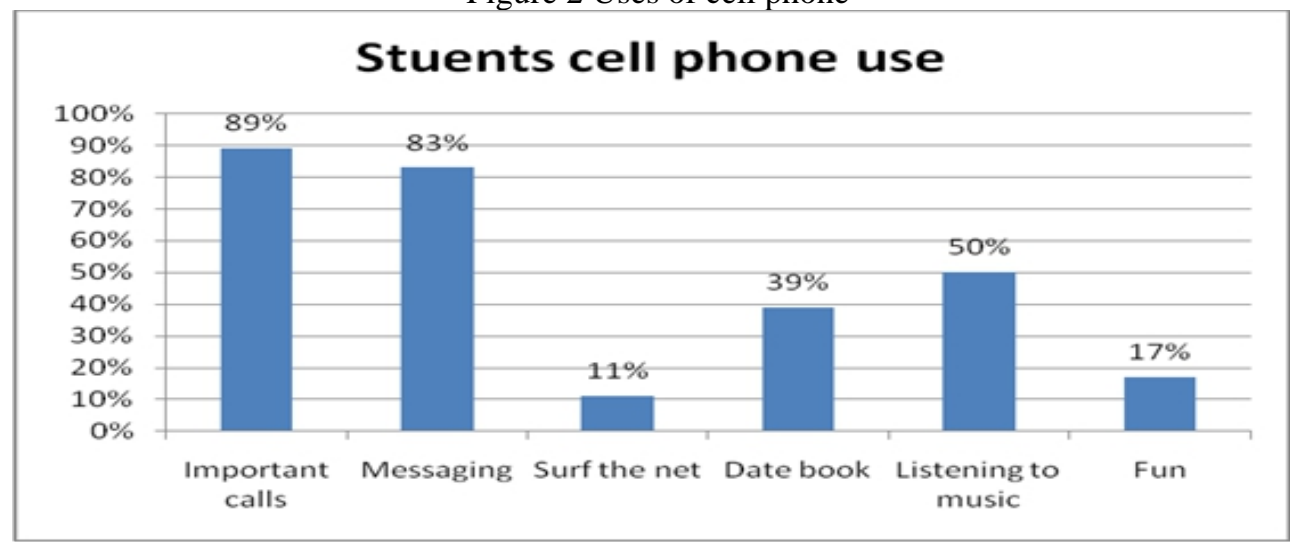

Regarding the information provided in figure $1,39 \%$ of the students have a PC and $72 \%$ have a laptop, $11 \%$ has both. According to the following table, computers are mostly used to have internet access, to work on school duties, to use specific programs or software such as office, java, auto cad among others and for fun.

Figure $3 \mathrm{PC}$ and laptops uses

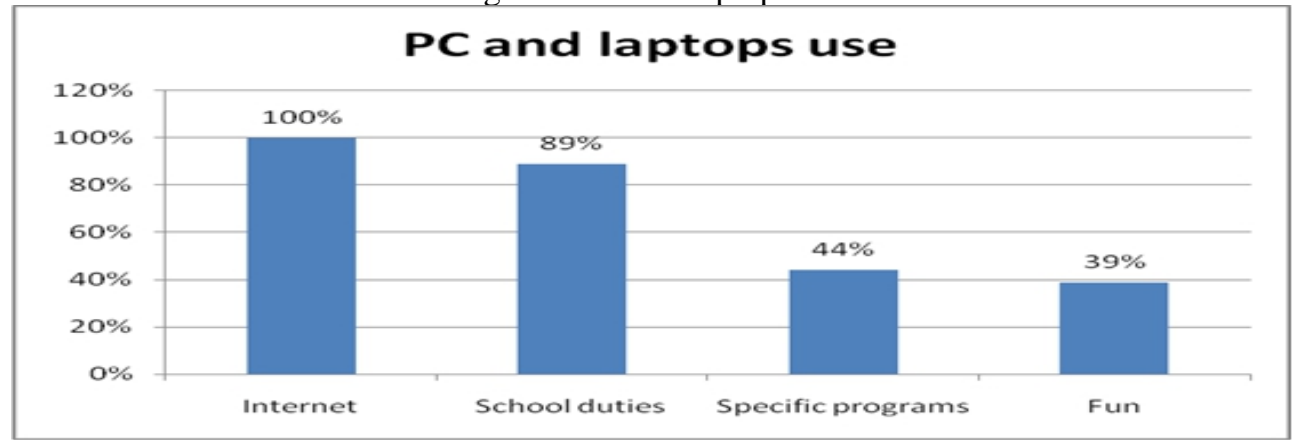

As we can see in the graphic above, surveyed students' number one priority for the use of computers is to have internet access $(100 \%$ of them considered the internet as number one). As they mentioned the major sites visited on the internet are: chats, social networks, e-mail accounts, blogs, internet searchers and music websites. (See figure 4)

Figure 4 Internet uses 


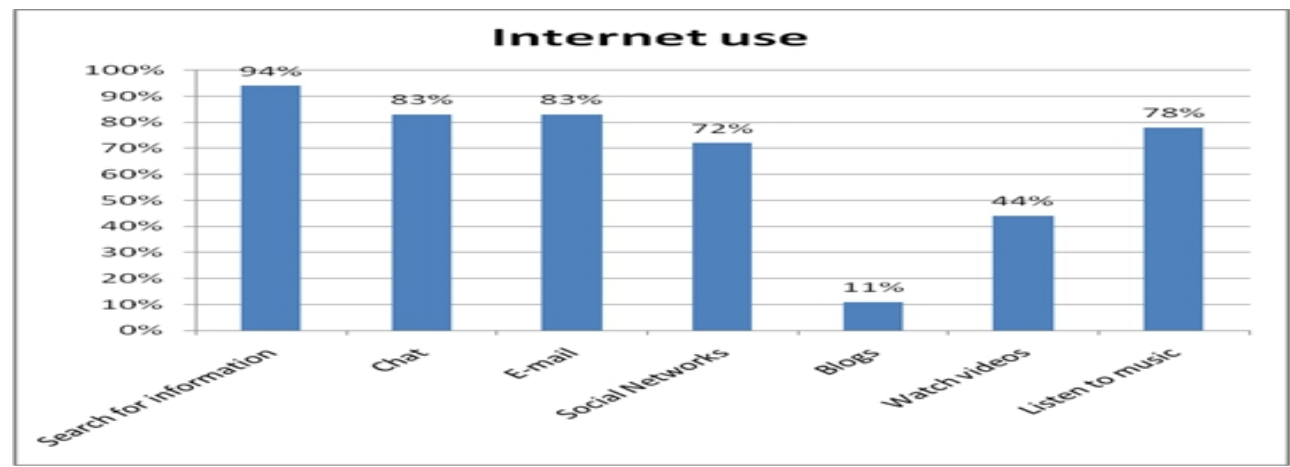

The different activities and web sites students use on the net are time consuming; for this reason one of the questions in the students' questionnaire asked them about the time they spend using any kind of technologies.

$72 \%$ of the students spend between four and six hours a day using technological tools and only $6 \%$ spend ten hours or more during a day. This information was provided by students through the questionnaire and it will be considered later again to talk about the time students spend using technologies for different purposes especially for academic issues. (See figure 5)

Figure 5 Average time per day that students dedicate to the use of technologies

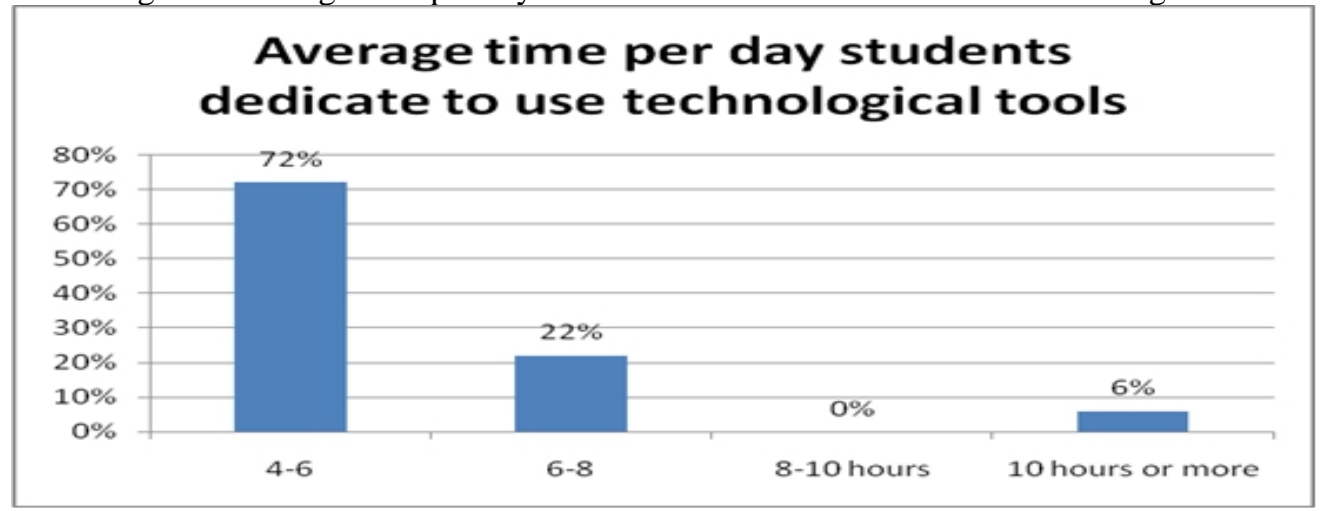

The same questionnaire asked the students about technologies available in their classrooms and technologies employed by teachers during a class, specifically English teachers. The most common technologies in classrooms are Pc's, internet connection, digital projectors, audio and video equipment. Considering these resources students mentioned that most of the teachers only employ digital projects leaving aside the rest of them or not considering the possibility to take some others for their classes. (See figure 6) 
Figure 6 Technological tools available in classrooms

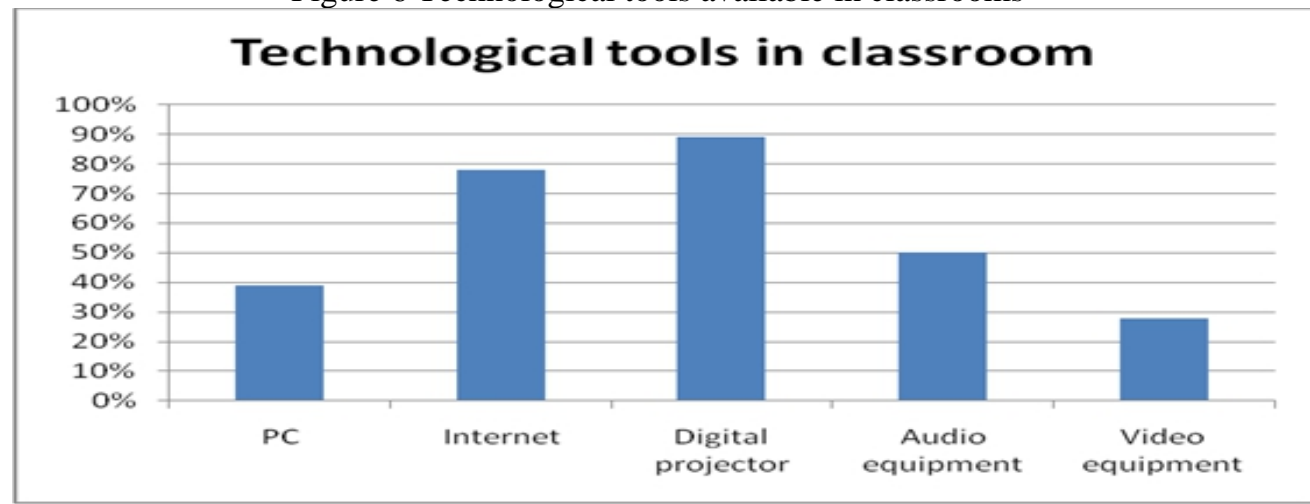

Figure 7 Technological elements employed by teachers

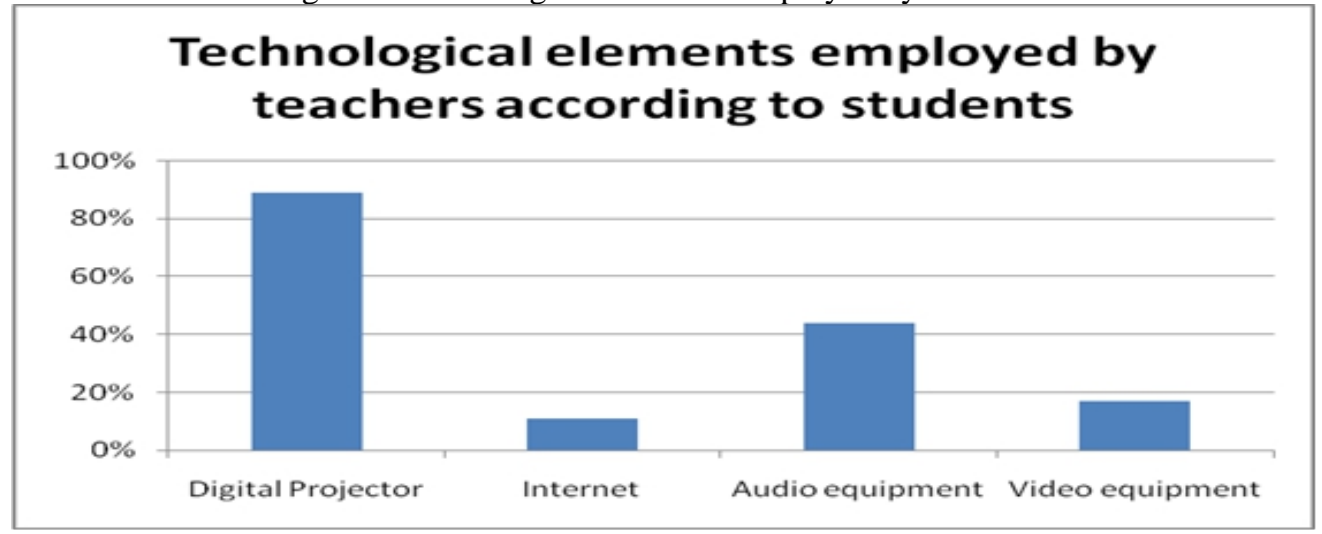

Previous information presented graphics and data related to representative numbers about the use of technologies for teachers according to students' opinions. The following information will be supported not only by information gathered through questionnaires but by the additional information obtained from interviews with students.

\section{Discussion}

Nowadays, a variety of new technological devices, software, gadgets and websites are available for many people and some of these elements have become favorites for students of different ages. This research study is focused on university English students at UAN.

As it was previously mentioned, a questionnaire was applied to a sample of students and a smaller sample of these students were considered to apply for further interviewes to know more about their preferences in technology and their most common uses in students' personal and academic lives. 
Through the questionnaires, it was possible to determine that students are well familiarized with the use of technology such as: the internet, computers (PC's and laptops), cell phones, video and audio equipment and especially with some internet applications such as e-mail accounts, chats, social networks and blogs.

The use of these technological resources will be divided in two aspects, uses for personal lives and uses for academic issues. It is important to make this division in order to know how the use of technology could impact on the academic aspect, especially in English language learning.

The next paragraph is showing the answers of the two research questions.

\section{RQ1What are the affordances of new technologies are used by students at the State University of Nayarit and what are their purposes for the use of these technologies?}

Most of the students mentioned the internet and computers as basic for their personal lives; they enjoy using the internet and spend about four to eight hours a day searching for information (academic and non-academic), checking their profiles in social networks, sending or forwarding e-mails and chatting with friends or exploring chat rooms to know more people.

According to students' comments, they like reading what others publish in their profiles in social networks and responding to others' comments. Students also like sending emails to friends and family members. Although this fact according to their own comments has decreased due to the warnings about the risk that represent to exchange personal information with unknown people.

Similarly, other favorite activities while using the internet is uploading pictures and videos captured with cell phones or handy cams, they even create titles and comments for them and expect others to express their ideas about what they uploaded.

Students also mentioned that cells phones have an important role for their personal lives. It is important to mention that modern cell phones or "smart-phones" have a lot of applications available, which make easier communication not only through phone calls. Nowadays cell phones are not only to make phone calls, according to students cell phones are used to send instant text messages, listening to music. They are also used such schedule organizers, take pictures and video and some others to surf the net among other applications depending on the cell phone style and brand. All the above mentioned only refers to uses that students make of technology for nonacademic purposes; this is only considered for their personal lives.

Even though, students make use of technologies and enjoy doing this, their use of technologies for academic purposes, it is reduced only to internet searches and the use of computers to specific software such as, office that 
includes: word processing programs, power point and excel. There is a noticeable contrast between the use that students make of technologies for academic and personal aspects that could be concluded that students are not interested in using technologies to learn a foreign language that they only use these resources to their homework or achieve school subject goals.

The second research question was:

\section{How could new technologies be best integrated in second language learning at the State University of Nayarit?}

First, different experts' opinions and points of view will be set and they will be considered to know more about the integration of technology in education.

For instance, (Salaberry, 2001:1) argued that "we are all in the midst of a microelectronic revolution" and pointed out that ignoring arrival of such revolutions carries negative effects. He also claimed that could be a potential waste of resources if pedagogy does not take advantage of technological tools.

Garret (1991), Salaberry (2001) and Murray (2005) in some of their research, remark that there is no consensus which considers the use of technologies in second language learning as something effective or as a nonfunctional approach, even when their investigations correspond to different decades. Both arguments support the idea that technologies should be integrated to education and in this particular case to language learning. Actually, technology has been in FLL for many years, when it was possible to record and the reproduce human voices, or to reproduce a video and use them to facilitate learning. There are different technologies such as audiovisual devices, internet and computers with their wide variety of applications and educational platforms which may be helpful to improve language learning.

The Public State University of Nayarit provides the opportunity to learn English as a Foreign language. In English as well in any other language, it is important to help students to be competent in the four skills of language, listening comprehension, reading comprehension, oral and writing production. Technologies can be applied to those skills and represent an extra aid for teachers and students. Audio devices provide extra support to develop students' phonetics, phonology and pronunciation, these devices allow students to listen many times to the pronunciation of a sound, with different accents and help them to practice their own pronunciation through the use of real voices, conversations and real situations.

For students at UAN this is a good form to have more practice considering that after English class they do not have an English context to keep practicing. 
Video devices are also good extra aids for English language learning, these devices also contribute to improve students pronunciation and identification of sounds. Futhermore, through the use of videos and images, students are able to identify meanings from context and this fact is possible more significant for them.

Salaberry (2001) argues that "videos expose students to authentic materials and voices, dialects and registers other than the teacher's and provide cultural context". In the same form, Platforms provide teachers the possibility to add more practice resources, different to those presented in syllabuses such: links with information about a specific grammatical structure, or extra exercises to have more practice, online available test for students to measure their own knowledge, online dictionaries and any other possibilities that teachers consider important to improve students' proficiency.

The use of platforms in the particular case of the State University of Nayarit, at that time when study was carried out students only had four hours of English instruction per week which is a limited time to develop high English language proficiency.

In order to decide in which way technologies would be best integrated to English language learning and to any other language is important to consider the following questions:

1. Is the level of technology sophistication directly related to the level of succeeding?

2. What technical attributes must be considered for being exploited for pedagogical purposes?

3. How can technologies be integrated to the curriculum?

4. Are new technologies more efficient than traditional technologies (e.g. overhead projector vs. power point presentations).

First, it is important to mention that the level of effectiveness and success of technologies in SLL is not completely determined by the types of technologies employed by teachers. Technologies are not self-directed and require teachers' direction, purpose and an aim to be used.

On the other hand, the level of sophistication does not guarantee the effectiveness to reach course aims. Educational programs must contain pedagogical aspects to provide students the adequate instruction and then select the technologies will be and extra aid to reach the goals. (Garret, 1991)

Technical attributes must be considered once the teaching program has been designed and the aims of the lesson have been established. Fortunately most of the technologies can be used for different purposes but they need to be decided before promote their use in classrooms.

For example, a computer provides internet access and students have thousands of possibilities to use English resources online. However, it is 
important that the teacher decide what is the best option to use in case a listening activity. For this purpose a teacher can select, songs, conversations and videos but will depend on what the student needs to do for the activity. In case they need to get specific information, probably the best option would be conversations, this way students practice their listening comprehension and to identify even when speakers have a different accent.

This study raised students' awareness about the common use of technology in their personal lives. On the other hand, some others students might have never used them before even for non-academic issues. Although, all students could use them to facilitate their learning process and improve their English language knowledge.

This study might help to consider the use of technology to be a motivational, tool for learning and reach their learning goals. Additionally, the use of technologies would provide them an extra advantage to be more competitive in a globalize world.

This study presented the current situation of the use of technologies for education in general and for second language learning. Furthermore, students' questionnaires revealed that they are more familiarized with technologies and their uses either for their personal lives and academic issues.

Figure 8 Technologies employed by students

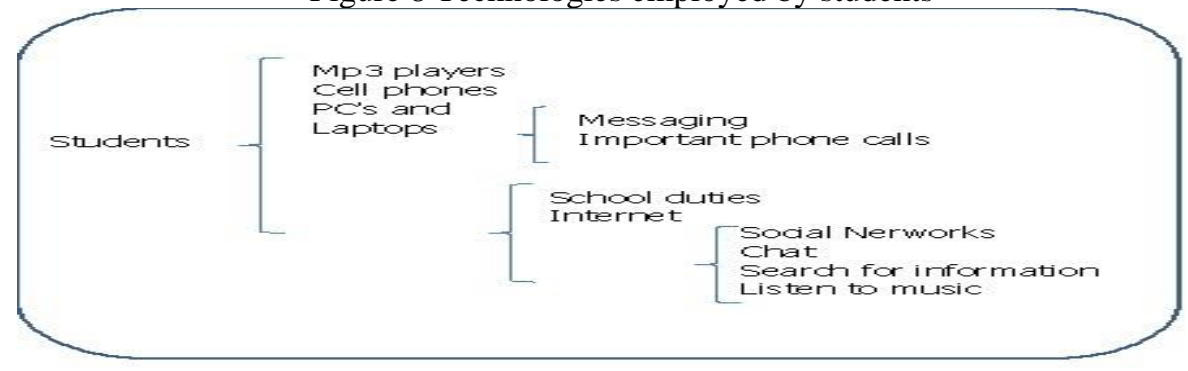

Prensky (2005) claims that students are no longer small versions of teachers. Students now are considered as digital natives and many teachers as digital natives. Nowadays, students are now more interested in technologies.

The aspect about the use of technologies in higher education, it is very important because it is not only related to the technological devices' function. Moreover, it is concern to the purpose of including some type of technology in courses and the aim of the lessons in order to reach an effective use of technologies.

The inclusion of technologies in EFL classrooms at UAN represents different challenges and in order to make an appropriate integration of them in EFL classrooms is necessary: 
1. Increase the technologies available in classrooms

2. Redirect students to the use of technologies for academic issues not only for their personal lives

\section{Conclusion:}

The study and research of the use of technologies in second language learning is still an unexplored field at the State University of Nayarit, however this short study reveals that there is too much work to do for the use of technologies in EFL classrooms.

Changes must start in the education systems and consider the inclusion of teachers, students and programs, also they should take into consideration the investment that these changes represent and the benefits that could be obtain with an adequate and efficient use of technologies for English language learning.

Teachers need to direct learning through a guide to help students to improve their proficiency level of English and have contact with native speakers or other speakers of English as a second language to have interaction and practice their sociolinguistic knowledge of English as a foreign language.

\section{References:}

1. Garret, N. 1991 Technology in the Service of Language Learning: Trend and Issues. The Modern Language Journal 75, 1:74-101

2. Godwin-Jones R. 2005 Emerging Technologies, Messaging, Gaming, Peer-to-Peer Sharing: Language Learning Strategies and Tools for the Millenial Generation. Language Learning and Technology9, 1:17-22

3. Murray, D. 2005 Technologies for Second Language Literacy. Annual Review of Applied Linguistics: 25, 188-201

4. Presnky, M. 2005 Listen to the Natives. Educational Leadership Publication: 63, 4:8-13

5. Salaberry, R. 2001 The Use of Technology for Second Language Learning and Teaching: A Retrospective. The Modern Language Journal 85, 1:39-56

6. Steinmueller, E. 2000. Will New Information and Communication Technologies Improve the Codification of Knowledge? Industrial and Corporate Change 9, 2:1-16 